\title{
Introduction to this Special Issue on Women in Oceanography
}

BY PEGGY DELANEY

It is my great pleasure to introduce this special issue of Oceanography magazine on "Women in Oceanography." The process began with a request from Ellen Kappel, the editor, to consider being guest editor for an issue on this topic and evolved through our discussions and considerations of various options (Articles by women oceanographers? Articles about women in oceanography?) and desired outcomes (truthful and positive, forward-looking and realistic). I had an incredible array of reactions, from being fascinated by the idea to being concerned that it could alienate people. I moved forward hoping that what would result would be a positive contribution to the field, helping set a direction for the future.

My own interests resulted from informal observations about oceanography combined with my long-standing interests in women in academia, science, and oceanography. I am not an expert on these topics, but I am curious about them, impelled to understand them.

Meeting sessions now have a significant proportion of women ocean scientists. I have recently served on several external review teams where program statistics documented that oceanography graduate students were now predominantly women. In contrast, the more senior ranks of academic ocean sciences, and sometimes the more junior ranks, did not seem significantly more diverse than they had been while I was in graduate school over two decades ago. We needed to move beyond the anecdotal and the informal.

As a result, we chose to focus the issue on a series of articles about women in ocean sciences encompassing statistical data and their analysis; programs aimed at improving the climate for women oceanographers; women oceanographers in a missionoriented agency; a web site displaying the diversity and lives of women in oceanography; personal observations about women in the field and their history; and a discussion of the larger place of oceanography in education and science. We coupled these articles with a series of autobiographical sketches of modern women in oceanography (see page 65). In this introduction, I wanted to offer a series of overarching observations and questions, rather than review the specific articles and topics in detail.

\section{OCEAN SCIENCES IN A LARGER CONTEXT}

The challenges and rewards facing women in academia and women in science occupy a substantial current literature (e.g., Academe, 2004, entire issue; Trower and Bleak, 2004; Wilson, 2004; Nelson, 2005), with some authors focusing specifically on issues related to the geosciences (e.g., Holmes et al., 2003; O'Connell and Holmes, this issue). Many academic institutions have convened task forces to assess the status of women scientists on their faculty (MIT Faculty Newsletter, 1999; Zakian et al., 2003) or of women faculty more generally (e.g., Sargent, 2001; Steering Committee for Women's Initiative, 2003). I found the statement of then-MIT President Charles M. Vest electrifying in its recognition of the problem (see box). In addressing issues about women in oceanography, we have a rich array of material available to begin defining and understanding the issues, and we should fully avail ourselves of this material.

Peggy Delaney (delaney@ucsc.edu) is Professor of Ocean Sciences, University of California, Santa Cruz, CA, USA. 
...I learned two particularly important lessons from this report and from discussions while it was being crafted. First, I have always believed that contemporary gender discrimination within universities is part reality and part perception. True, but I now understand that reality is by far the greater part of the balance. Second, I, like most of my male colleagues, believe that we are highly supportive of our junior women faculty members. This also is true. They generally are content and well supported in many, though not all dimensions. However, I sat bolt upright in my chair when a senior woman, who has felt unfairly treated for some time, said 'I also felt very positive when I was young'...

Comments made by MIT's former president, Charles M. Vest, in March 1999 in the MIT Faculty Newsletter, when introducing a special issue on "A Study on the Status of Women Faculty in Science at MIT."

\section{ACKNOWLEDGEMENT THAT DIFFERENCES WARRANT INVESTIGATION}

There is no simple answer to "what proportion of women oceanographers would be the correct proportion?" although statistical data about pipeline issues and differences in representation in different areas can frame the issues. It is often difficult for individuals in oceanography, who themselves are dedicated to gender equality in their personal and professional lives, to stand back far enough to see the situation without emotion. It requires that we acknowledge that observed differences in representation by gender at different career levels warrant reasoned and dispassionate investigation. Differential outcomes for classes of scientists can result even when not intended by any single individual or process design.

\section{PEOPLE AND PROGRAMS CAN MAKE A DIFFERENCE}

I am a persistent optimist, so despite the apparently daunting professional, personal, and institutional challenges, I am optimistic that we can create and nurture effective solutions. For example, in this issue, we include two articles about programs focused on the progress and career tracks of women in oceanography in one sub-discipline of oceanography (Lozier, this issue) and in one oceanographic institution (Bell et al., this issue). Both programs are designed intentionally as scaleable experiments to be adopted elsewhere and aimed at building a sustainable infrastructure and climate.

\section{WHAT IS MISSING?}

In many ways, there are more things missing from this issue than are included. Most of the articles and statistics included in them focus on the United States, though many of the autobiographical sketches are from non-U.S. scientists. There are undoubtedly other efforts about diversity in the field that we missed chronicling. The process of soliciting the autobiographies and the resulting e-mail correspondence highlighted a lack of a comprehensive history of women in oceanography at the level of specific individuals and of the field as a whole. Some of our women oceanographic pioneers are no longer living, and others are retired or soon to retire. While this issue covers some statistical data about women primarily in academic oceanography and in the context of the geosciences, we lack a systematic analysis of women in oceanography, including a broader range of job titles and career paths. Finally, we don't 
explore the understanding of representation of racial and ethnic minorities in oceanography and the intersection this can have with gender.

\section{OPPORTUNITY FOR OCEAN SCIENCES}

Why do the issues of gender representation in oceanography represent an opportunity? Given the representation of women in graduate school in oceanography, there is no time like the present to tackle these issues. Oceanographers are, by orientation and practice, a field of problem solvers, comfortable with interdisciplinary issues and with envisioning complex, interdependent systems. Finally, it is my belief that improving opportunities for the success of all oceanographers, both men and women, will benefit oceanography.

\section{ACKNOWLEDGEMENTS}

We would like to thank all the program officers and financial sponsors of this issue, who enthusiastically supported the idea at all stages. Sponsoring agencies include the National Aeronautics and Space Administration, the National Oceanic and Atmospheric Administration, the National Science Foundation, the Office of Naval Research, and the U.S. Geological Survey. We thank all the authors and contributors to this issue and, most importantly, the oceanographers who care about this issue and the field as a whole. 四

\section{REFERENCES}

Academe. 2004. Bulletin of the American Association of University Professors. Special issue on "Balancing Faculty Careers and Family Work". Academe 90(6): entire issue. [Online] Available at: http://www.aaup.org/publications/ Academe/2004/04nd/04ndtoc.htm.

Holmes, M.A., S. O'Connell, C. Frey, and L.K. Ongley. 2003. Academic specialties in U.S. are shifting; hiring of women geoscientists is stagnating. Eos, Transactions of American Geophysical Union 84(43):457, 460-461.

Members of the First and Second Committees on Women Faculty in the School of Science. 1999. A study on the status of women faculty in science at MIT, The MIT Faculty Newsletter, Special Edition, Vol. XI (4), March 1999. [Online] Available at: http://web.mit.edu/fnl/women/women.html.

Nelson, D.J. 2005. A National Analysis of Diversity in Science and Engineering Faculties at Research Universities. University of Oklahoma, Norman, OK. [Online] Available at: http://cheminfo.chem.ou.edu/ djn/diversity/briefings/Diversity\%20Report\%20Final.pdf.

Steering Committee for Women's Initiative. 2003. Women's Initiative, Duke University. Report of the Steering Committee for the Women's Initiative at Duke University. [Online] Available at: http://www.duke.edu/womens_initiative/report_report.htm.

Trower, C.A. and J.L Bleak. 2004. The Study of New Scholars. Race: Statistical Report [Universities]. Harvard School of Education, Cambridge, MA.

Sargent, A.I. 2001. Committee on the Status of Women Faculty at Caltech: Final Report [Online] Available at: http://diversity.caltech.edu/CSFWFINALREPORT1.pdf.

Wilson, R. 2004. "Where the elite teach, it's still a man's world: The women who do get hired at major research universities often find a 'toxic atmosphere"” Chronicle of Higher Education (Dec. 3):A8-A9, A12, A14.

Zakian, V., B. Draine, L. Ferrand, J. Girgus, R. Lee, C. Paxson, C. Peters, D. Rubenstein, S. Troian, S. Walker, and B. Ward. 2003. Report of the Task Force on the Status of Women Faculty in the Natural Sciences and Engineering at Princeton. [Online] Available at: http://www.princeton.edu/pr/reports/sciencetf/.

\section{Upcoming Events}

\section{International Ocean} Research Conference

June 6-10, 2005

Paris, France

www.tos.org/2005_iorc

\section{Dynamic Planet 2005}

August 22-26, 2005

Cairns, Australia

www.dynamicplanet2005.com
DIALOG VII Symposium

December 3-10, 2005

Dauphin Island Sea Lab

aslo.org/dialog/dialogposter.pdf

2006 Ocean Sciences Meeting

February 20-24, 2006

Honolulu, Hawaii

www.agu.org/meetings 